\title{
Impact of Duodenal-Jejunal Exclusion on Satiety Hormones
}

Citation for published version (APA):

de Jonge, C., Rensen, S. S., Verdam, F., Vincent, R. P., Bloom, S. R., Buurman, W. A., le Roux, C. W., Bouvy, N. D., \& Greve, J. W. (2016). Impact of Duodenal-Jejunal Exclusion on Satiety Hormones. Obesity Surgery, 26(3), 672-678. https://doi.org/10.1007/s11695-015-1889-y

Document status and date:

Published: 01/03/2016

DOI:

10.1007/s11695-015-1889-y

Document Version:

Publisher's PDF, also known as Version of record

Document license:

Taverne

Please check the document version of this publication:

- A submitted manuscript is the version of the article upon submission and before peer-review. There can be important differences between the submitted version and the official published version of record.

People interested in the research are advised to contact the author for the final version of the publication, or visit the DOI to the publisher's website.

- The final author version and the galley proof are versions of the publication after peer review.

- The final published version features the final layout of the paper including the volume, issue and page numbers.

Link to publication

\footnotetext{
General rights rights.

- You may freely distribute the URL identifying the publication in the public portal. please follow below link for the End User Agreement:

www.umlib.nl/taverne-license

Take down policy

If you believe that this document breaches copyright please contact us at:

repository@maastrichtuniversity.nl

providing details and we will investigate your claim.
}

Copyright and moral rights for the publications made accessible in the public portal are retained by the authors and/or other copyright owners and it is a condition of accessing publications that users recognise and abide by the legal requirements associated with these

- Users may download and print one copy of any publication from the public portal for the purpose of private study or research.

- You may not further distribute the material or use it for any profit-making activity or commercial gain

If the publication is distributed under the terms of Article $25 \mathrm{fa}$ of the Dutch Copyright Act, indicated by the "Taverne" license above, 


\title{
Impact of Duodenal-Jejunal Exclusion on Satiety Hormones
}

\author{
Charlotte de Jonge $^{1,2} \cdot$ Sander S. Rensen ${ }^{1} \cdot$ Froukje J. Verdam ${ }^{1} \cdot$ Royce P. Vincent ${ }^{3}$. \\ Steve R. Bloom ${ }^{4}$ - Wim A. Buurman ${ }^{5}$ - Carel W. le Roux ${ }^{4,6}$ • Nicole D. Bouvy ${ }^{1}$ • \\ Jan Willem M. Greve $e^{2,7}$
}

Published online: 7 October 2015

(C) Springer Science+Business Media New York 2015

\begin{abstract}
Objective Bariatric procedures that exclude the proximal small intestine lead to significant weight loss which is probably mediated by changes in hormones that alter appetite, such as peptide YY (PYY), ghrelin, cholecystokinin (CCK), and leptin. Here, the effect of the non-surgical duodenal-jejunal bypass liner (DJBL) on concentrations of hormones implicated in appetite control was investigated.

Subjects A two-center prospective study was conducted between January and December 2010. Seventeen obese subjects with type 2 diabetes were treated with the DJBL for 24 weeks. Fasting concentrations of leptin and meal responses of plasma PYY, CCK, and ghrelin were determined prior to and after implantation of the DJBL.

Results At baseline, subjects had an average body weight of $116.0 \pm 5.8 \mathrm{~kg}$. One week after implantation, subjects had lost
\end{abstract}

Jan Willem M. Greve

j.greve@atriummc.nl

Charlotte de Jonge

c.dejonge@maastrichtuniversity.nl

Sander S. Rensen

s.rensen@maastrichtuniversity.nl

Froukje J. Verdam

F.J.Verdam@umcutrecht.nl

Royce P. Vincent

royce.vincent@nhs.net

Steve R. Bloom

s.bloom@imperial.ac.uk

Wim A. Buurman

w.buurman@maastrichtuniversity.nl

Carel W. le Roux

carel.leroux@ucd.ie

Nicole D. Bouvy

n.bouvy@maastrichtuniversity.nl
$4.3 \pm 0.6 \mathrm{~kg}(p<0.01)$, which progressed to $12.7 \pm 1.3 \mathrm{~kg}$ at week $24(p<0.01)$. Postprandial concentrations of PYY and ghrelin increased (baseline vs. week 1 vs. week 24 PYY: $2.6 \pm$ 0.2 vs. $4.1 \pm 0.4$ vs. $4.1 \pm 0.7 \mathrm{nmol} / \mathrm{L} / \mathrm{min}$ and ghrelin: $7.8 \pm 1.8$ vs. $11.0 \pm 1.8$ vs. $10.6 \pm 1.8 \mathrm{ng} / \mathrm{mL} / \mathrm{min}$, all $p<0.05$ ). In parallel, the CCK response decreased (baseline vs. week 1 vs. week 24: $434 \pm 51$ vs. $229 \pm 52$ vs. $256 \pm 51 \mathrm{pmol} / \mathrm{L} / \mathrm{min}, p<0.01$ ). Fasting leptin concentrations also decreased (baseline vs. week $24: 98 \pm 17$ vs. $53 \pm 10 \mathrm{ng} / \mathrm{mL}, p<0.01$ ).

Conclusions DJBL treatment induces weight loss paralleled by changes in concentrations of hormones involved in appetite control.

Keywords Satiety $\cdot$ Bariatric surgery $\cdot$ Obesity $\cdot$ Gut hormones
1 Department of General Surgery and NUTRIM School for Nutrition, Toxicology and Metabolism, Maastricht University Medical Center, P. Debyelaan 25, 6229 HX Maastricht, The Netherlands

2 Department of General Surgery, Atrium Medical Center Parkstad, Henri Dunantstraat 5, 6419 PC Heerlen, The Netherlands

3 Department of Clinical Biochemistry, King's College Hospital NHS Foundation Trust, Denmark Hill, SE5 9RS London, UK

4 Department of Medicine, Imperial College London, Du Cane Road, W12 0NN London, UK

5 School for Mental Health and Neuroscience, Maastricht University Medical Center, P. Debyelaan 25, 6229

HX Maastricht, The Netherlands

6 Department of Experimental Pathology, UCD Conway Institute, School of Medicine and Medical Science, University College Dublin, Belfield Dublin 4, Dublin, Ireland

7 Department of General Surgery, Atrium Medical Center Parkstad, PO box 4446, 6401 CX Heerlen, The Netherlands 


\section{Introduction}

Maintaining weight loss following treatment of obesity with lifestyle interventions or drugs remains a challenge $[1,2]$. Bariatric surgery is considered to be an effective strategy to achieve long term reduction of body weight [3] because it increases satiety and decreases caloric intake $[4,5]$. These changes seem to be mediated by changes in appetite regulating hormones, such as peptide YY (PYY), glucagon-like peptide-1 (GLP-1), cholecystokinin (CCK), ghrelin, and leptin [6-8].

Whereas CCK, PYY, GLP-1, and ghrelin are gut hormones predominantly involved in short term signaling in relation to intraluminal food content, the adipokine leptin, is a long term regulator of energy balance [9]. In obese individuals, plasma CCK levels have been reported to be low [10], and postprandial PYY response is attenuated [11], while ghrelin levels are also low $[12,13]$. Furthermore, obesity is characterized by high levels of leptin which do not temper appetite because of leptin resistance $[9,14]$.

Bariatric procedures have been suggested to alter hormonal responses thereby affecting satiety. In particular, the Roux-en-Y gastric bypass (RYGB) leads to increased satiety and postprandial PYY and GLP-1 levels [15-17]. Little is known about changes in the CCK response after bariatric surgery [18, 19], while the effects on ghrelin levels are controversial $[18,20]$. Leptin levels have been reported to decrease after bariatric procedures, mirroring weight loss [21].

Recently, a non-surgical bariatric technique, the duodenaljejunal bypass liner (DJBL, GI Dynamics, Lexington, MA), was developed to treat obesity. The DJBL is a $60-\mathrm{cm}$ long impermeable liner which is delivered and retrieved endoscopically. Once in place, it mimics the intestinal bypass component of the RYGB. Previously, DJBL treatment has been shown to result in weight loss and improvement of type 2 diabetes [22-24].

We aimed to investigate the effect of duodenal-jejunal exclusion by DJBL on fasting and postprandial plasma concentrations of hormones involved in appetite control. CCK, ghrelin, and PYY responses to a standard meal and fasting leptin levels were studied in subjects with obesity and type 2 diabetes prior to and after DJBL implantation.

\section{Subjects and Methods}

\section{Subjects}

Seventeen subjects with obesity and type 2 diabetes were included in the Maastricht University Medical Center, Maastricht, and the Atrium Medical Center Parkstad, Heerlen, the Netherlands. Inclusion criteria were as follows: age between 18 and 65 years; body mass index (BMI) between 30 and $50 \mathrm{~kg} / \mathrm{m}^{2}$; duration of type 2 diabetes less than 10 years; and $\mathrm{abbA}$ c between 7.5 and $10.0 \%$. Main exclusion criteria were as follows: weight loss of more than $4.5 \mathrm{~kg}$ within 12 weeks prior to screening; use of weight loss medication; use of anticoagulation medication, NSAIDs, or corticosteroids; iron deficiency or anemia; gastrointestinal abnormalities; gastroesophageal reflux disease; symptomatic gallstones or kidney stones; known infection including Helicobacter pylori; history of coagulopathy or upper gastrointestinal bleeding conditions, connective tissue disorder, and severe kidney or liver failure. All procedures performed were in accordance with the ethical standards of the institutional and/or national research committee and with the 1964 Helsinki declaration and its later amendments or comparable ethical standards. Informed consent was obtained from all individual participants included in the study.

\section{The DJBL Procedure}

The DJBL was delivered and retrieved endoscopically as previously described [23]. In brief, a gastroduodenal endoscopy was performed under general anesthesia. A guide wire was placed into the duodenum over which the encapsulated DJBL was directed through the pylorus into the duodenal bulb. The DJBL was advanced into the small intestine, followed by deployment of the anchor in the duodenal bulb. Correct positioning and patency of the DJBL were verified under fluoroscopy.

After 24 weeks, removal of the DJBL was performed endoscopically under general anesthesia by the use of a custom retrieval system containing a grasper and a retrieval hood. By grasping the retrieval suture on the proximal face of the anchor, the anchor collapsed and was pulled into the retrieval hood at the distal end of the endoscope. After verification of the collapsed anchor by fluoroscopy, the device was removed.

\section{Study Design}

Subjects were studied on three occasions: (1) within 1 month prior to implantation, (2) 1 week after implantation, and 3) 24 weeks after implantation, just prior to removal. After implantation of the DJBL, subjects were provided a standard of care bariatric nutritional counseling program, which suggested a regular diet with a maximum of $1200 \mathrm{kcal}$ for women and $1500 \mathrm{kcal}$ for men. For safety reasons, liquid nutrition was advised for the first week after DJBL placement. At every visit, body weight was determined and subjects were asked if their satiety and caloric intake had increased, decreased, or was unchanged when compared to baseline. Daily caloric intake was evaluated by a dietitian and if necessary, dietary adaptations were made. Additionally, a standardized meal tolerance test was performed: venous blood samples were drawn after an overnight fast; subsequently a standard liquid meal 
was consumed (Ensure Plus, Abbott Laboratories, IL; $333 \mathrm{~mL}, 500 \mathrm{kcal}, 20.8 \mathrm{~g}$ protein, $67.3 \mathrm{~g}$ carbohydrates, and $16.4 \mathrm{~g}$ fat), followed by collection of blood samples after 10 , 30, 60, 90, and 120 min (BD Vacutainer EDTA tube/EDTA aprotinin tube, BD diagnostics, Erembodegem-Aalst, Belgium). Samples were immediately cooled, centrifuged, and stored at $-80^{\circ} \mathrm{C}$ until analysis.

\section{Plasma Hormone Assays}

Plasma levels of total PYY and leptin were measured respectively by radioimmunoassay and sandwich ELISA, as previously described $[25,26]$. Plasma CCK was determined using a commercially available CCK-radioimmunoassay according to the manufacturer's protocol (Euro-diagnostica, Malmö, Sweden). Plasma active ghrelin concentrations were assessed with the human diabetes bio-plex pro assay (Bio-Rad Laboratories BV, Veenendaal, the Netherlands) using Luminex xMAP technology. The assay was performed with a Luminex 100 IS 2.3 system using Bio-Plex Manager 4.1.1. software as described by the manufacturer's instructions.

\section{Statistical Analyses}

GraphPad Prism 5.0 and Statistical Package for Social Sciences 17.0 were used. The area under the curve (AUC) was calculated using GraphPad Prism. Longitudinal changes were tested with linear mixed models in SPSS. The correct covariance structure for the repeated measures was chosen according to Akaike Information Criterion and Bayesian Information Criterion values. Nonparametric bivariate correlations were tested with Spearman's correlation coefficient. A $p$ value of $<0.05$ was considered statistically significant. Data are presented as statistical model estimated mean and standard error of the mean (SEM).

\section{Results}

\section{Exclusion of the Proximal Small Intestine by DJBL Affects Body Weight}

At baseline, subjects ( 14 males, 3 females) were $51 \pm 2$ years old and weighed $116.0 \pm 5.8 \mathrm{~kg}$ with a BMI of $37.0 \pm 1.3 \mathrm{~kg} /$ $\mathrm{m}^{2}$. One week after placement of the DJBL, body weight had decreased by $4.3 \pm 0.6 \mathrm{~kg}$, corresponding to an excess weight loss of $10.2 \pm 1.7 \%$ and a BMI reduction of $1.4 \pm 0.2 \mathrm{~kg} / \mathrm{m}^{2}$ $(p<0.01)$. After 24 weeks, at the time of device removal, mean body weight had further decreased resulting in a total weight loss of $12.7 \pm 1.3 \mathrm{~kg}$, with an excess weight loss of $29.8 \pm 3.5 \%$ and a BMI reduction of $4.1 \pm 0.4 \mathrm{~kg} / \mathrm{m}^{2}(p<0.01)$. All subjects reported a reduction in caloric intake during the study, and $88 \%$ of the subjects $(15 / 17)$ reported increased satiety.

\section{Rapid increase of PYY After DJBL Implantation}

As shown in Fig. 1a, prior to DJBL placement, PYY only increased marginally in response to a meal. Within 1 week after placement, the AUC of the PYY response increased significantly (baseline: $2.6 \pm 0.2$ vs. week $1: 4.1 \pm 0.4 \mathrm{nmol} / \mathrm{L} / \mathrm{min}$, $p<0.01$, Fig. 1b). This increase sustained during the remainder of the study period (baseline: $2.6 \pm 0.2$ vs. week $24: 4.1 \pm$ $0.7 \mathrm{nmol} / \mathrm{L} / \mathrm{min}, p<0.05)$. Furthermore, fasting PYY levels

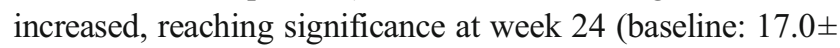
1.5 vs. week $24: 23.1 \pm 2.7 \mathrm{pmol} / \mathrm{L}, p<0.05$ ).

\section{Decreased Postprandial CCK Response After DJBL Implantation}

Before DJBL placement, CCK levels increased rapidly following meal ingestion (Fig. 1c). After DJBL placement, this postprandial peak was still observed, but the maximal CCK concentration decreased strongly from $7.8 \pm 1.2 \mathrm{pmol} / \mathrm{L}$ at baseline to $3.3 \pm 1.1$ and $3.8 \pm 1.0 \mathrm{pmol} / \mathrm{L}$ at week 1 and week 24, respectively. This resulted in a decreased AUC for CCK (baseline: $434 \pm 51$ vs. week 1: $229 \pm 52$ and baseline: $434 \pm 51$ vs. week 24: $256 \pm 51 \mathrm{pmol} / \mathrm{L} / \mathrm{min}$, both $p<0.01$, Fig. 1d).

\section{DJBL Treatment Results in Changes in Fasting and Postprandial Ghrelin Levels}

A postprandial decline in plasma levels of ghrelin, suggesting inhibition of hunger after meal consumption, was present at baseline (Fig. 1e). After DJBL placement, fasting ghrelin levels increased (baseline: $38.8 \pm 19.9$ vs. week 1: $120.7 \pm$ $20.2 \mathrm{pg} / \mathrm{mL}$ and baseline: $38.8 \pm 19.9$ vs. week $24: 137.1 \pm$ $19.9 \mathrm{pg} / \mathrm{mL}, p<0.05$ and $p<0.01$ respectively). Interestingly, the difference between fasting and nadir ghrelin levels also increased after placement of the DJBL, resulting in comparable nadir of plasma ghrelin levels at $90 \mathrm{~min}$ postprandially. Though, the AUC for ghrelin increased after DJBL placement (baseline: $7.9 \pm 1.8$ vs. week 1: $11.0 \pm 1.8 \mathrm{ng} / \mathrm{mL} / \mathrm{min}$ and baseline: $7.9 \pm 1.8$ vs. week $24: 10.6 \pm 1.8 \mathrm{ng} / \mathrm{mL} / \mathrm{min}, p<0.05$ and $p<0.01$, respectively, Fig. 1f).

\section{Leptin Levels Decrease in Relation to Weight Loss After DJBL Implantation}

At baseline, fasting plasma leptin levels correlated with BMI $\left(\mathrm{r}_{\mathrm{s}}=0.65, p<0.01\right)$. After DJBL placement, leptin levels decreased, reaching statistical significance at week 24 (baseline: $98 \pm 17$ vs. week 1: $80 \pm 15 \mathrm{ng} / \mathrm{mL}$ and baseline: $98 \pm 17$ vs. week 24: $53 \pm 10 \mathrm{ng} / \mathrm{mL}, p=0.11$ and $p<0.01$, respectively, Fig. 1g). In addition, plasma leptin levels and BMI remained correlated at both week 1 and week 24 (week 1: $\mathrm{r}_{\mathrm{s}}=0.87$, $p<0.01$ and week 24: $\mathrm{r}_{\mathrm{s}}=0.58, p=0.02$, respectively). 
Fig. 1 Effects of DJBL treatment on fasting and postprandial PYY, CCK, ghrelin, and fasting leptin. a Plasma PYY concentrations during the meal tolerance test at baseline, 1 week after implantation of the DJBL, and just prior to DJBL explantation. b The area under the curve calculations for PYY. c Plasma CCK concentrations obtained during the meal tolerance tests and $\mathbf{d}$ shows the area under the curve calculations for CCK. e Plasma ghrelin levels during the meal tolerance tests whereas f displays the area under the curve calculations for ghrelin. $g$ The fasting leptin plasma levels. An asterisk $(*)$ indicates $p<0.05$, two asterisks indicate $p<0.01$. The orange circles represent the baseline time point, the dark blue blocks represent the week 1 time point, and the ss represent the week 24 time point

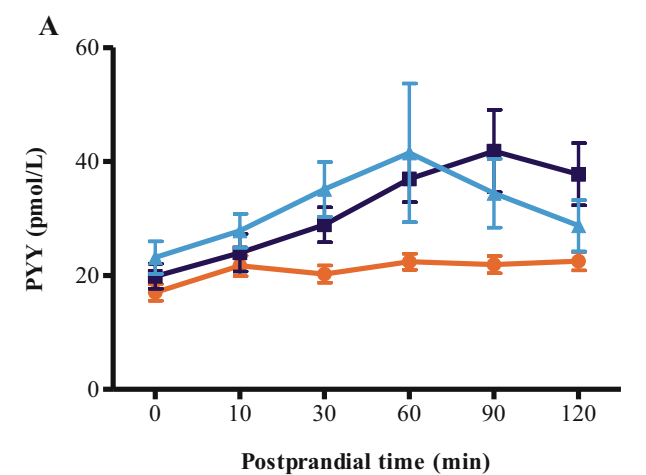

Week $1 \multimap$ Week 24
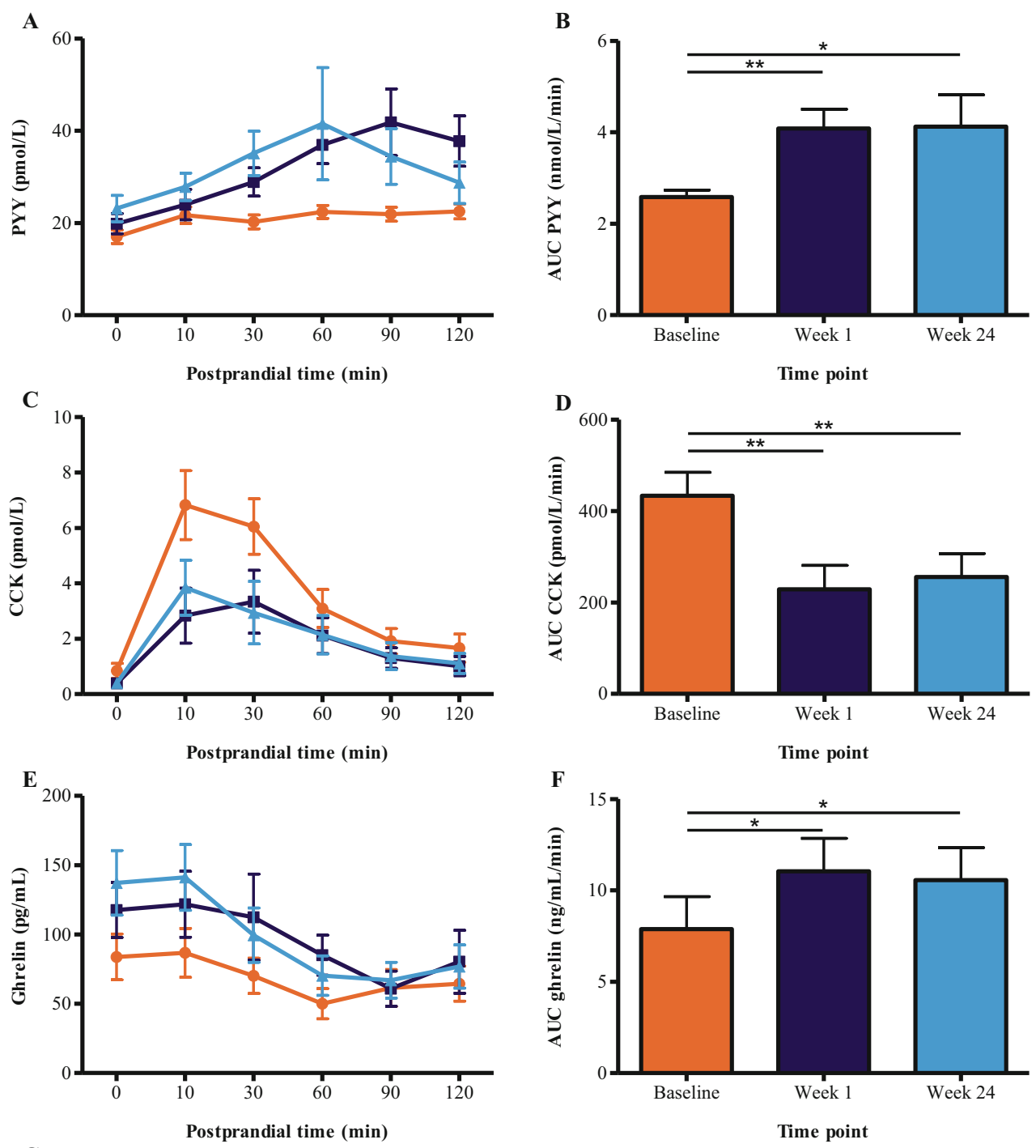

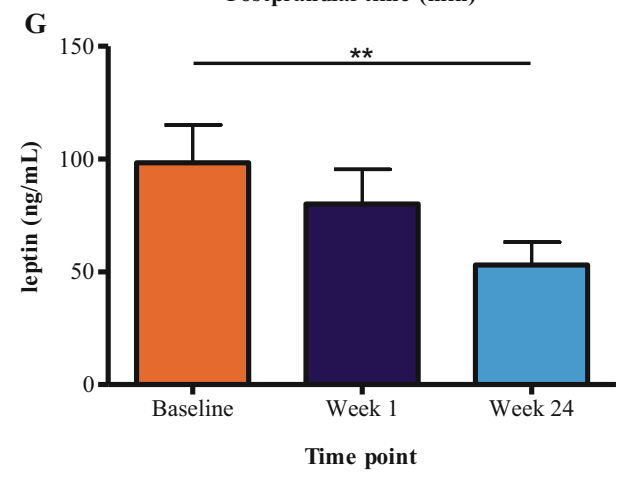

\section{Discussion}

Bariatric surgery leads to extensive weight loss. Additionally, several changes in human physiology occur; alterations in satiety, taste, and food preference have been described $[27,28]$. These changes are considered essential for losing weight. Bypassing the duodenum and jejunum by DJBL treatment has previously been shown to induce weight loss $[22,23]$. In the current study, the effect of the DJBL on satiety hormones CCK, PYY, ghrelin, and leptin was investigated.

Whereas CCK is secreted in the proximal small intestine in response to intraluminal nutrients and signals satiety via vagal afferents [29], PYY is secreted by L-cells predominantly in the distal gastrointestinal tract and reduces food intake by 
increasing satiety and reducing gut motility [30, 31]. Secretion of the orexigenic hormone ghrelin, mainly by the stomach fundus, is stimulated in the fasted state and plasma levels fall shortly after food ingestion [32, 33]. Leptin is secreted by adipocytes in proportion to whole body adipose tissue mass and is a long term energy regulator.

In obese subjects, various aberrations in satiety regulation have been described, with leptin resistance as the most reported feature [34]. In addition, obesity is associated with altered hormonal responses to food [11]. RYGB augments postprandial PYY and GLP-1 levels and increases satiety [15-18]. In line, the current study shows that the postprandial PYY response was increased after implantation of the DJBL. Previously, we reported on increased postprandial GLP-1 levels in DJBL treated patients [24]. Interestingly, subjects treated with the DJBL also reported increased satiety and reduced caloric intake. The underlying mechanism for the increased PYY and GLP-1 levels might be related to the presence of undigested nutrients in the distal gut, where PYY and GLP-1 secreting cells are predominantly located. Both the RYBG and the DJBL prevent uptake and digestion of nutrients in the proximal small intestine. As a result, undigested nutrients will be present more distally in the small intestine [30, 31]. In accordance to the ileal brake theory, intestinal feedback mechanisms, such as PYY and GLP-1, are activated by undigested nutrients in the distal gut, reducing food intake and increasing satiety by delaying gut motility $[35,36]$.

To obtain insight into changes in additional hormones involved in appetite control, postprandial levels of CCK, a hormone with important digestive and satiety functions, were determined. After implantation of the DJBL, the CCK response to a meal decreased. We propose that the absence of direct contact of food with the proximal small gut, where the CCK producing I-cells are predominantly located, might explain the decreased CCK response after DJBL treatment. This decrease in CCK levels could lead to a decrease in satiety. However, in obese subject CCK resistance has been suggested [37], putatively reducing the aforementioned effect.

Furthermore, DJBL implantation resulted in an enhanced postprandial ghrelin response. After DJBL placement, fasting ghrelin levels were increased but a more distinct postprandial reduction in concentrations was present. Taking into account the wide spectrum of physiological functions of ghrelin $[33,38]$ and the controversial results obtained following other bariatric procedures [20], these changes are not easily explained. However, the more pronounced decrease in postprandial ghrelin levels after DJBL placement might be associated with increased satiety following meal ingestion. Furthermore, although the stomach is the principal site of ghrelin production, up to one third of the circulating ghrelin is thought to originate from the proximal small intestine [39]. The increased (fasting) ghrelin levels might therefore be induced by the exclusion of this part of the intestine from nutrients, thereby locally mimicking starvation. Additionally, circulating ghrelin levels have been reported to be inversely correlated with adipose tissue mass $[12,13]$. The subjects in the current study lost a significant amount of weight; therefore, loss of adipose tissue mass might be expected. In line, leptin levels decreased along with BMI, presumably reflecting reduced adipose tissue mass $[18,21]$.

Subjects included in the current study suffered from both obesity and type 2 diabetes. In these subjects, with insulin resistance, satiety control is probably even more disturbed than in subjects with obesity alone since insulin is involved in satiety control via signaling of long term energy stores [40]. Interestingly, increased insulin sensitivity has been reported following both bariatric surgery [41] and DJBL placement $[22,24,42]$.

A limitation of our study is the uncontrolled nature of the study. Patients were advised calorie restriction in combination with DJBL treatment. Studies comparing the combination of bariatric surgery with dietary regimens to dietary restriction alone are scarce. Evens, et al., described an increase in the postprandial PYY and GLP-1 levels after RYGB independent of caloric restriction [43]. However, the effect of weight loss due to caloric restriction, especially on the longer term, cannot be excluded.

In conclusion, our data show that DJBL treatment induces weight loss paralleled by changes in plasma concentrations of hormones involved in appetite control. The improved hormonal profiles may attenuate weight regain after removal of the DJBL or aid the effectiveness of other therapies to maintain weight loss.

Acknowledgments The authors would like to thank the subjects contributing to this trial; the trial nurses Y. Wils and R. Nelissen, and the students who helped conducting this research: G. Latten, N. Geubbels, M. de Wolf, T. van der Horst, R. Erbil, B. van der Putten, H. D'Agnolo, S. Peeters Weem, and M.A. Joosten; B. Winkens for statistical assistance; Dr. R.J. de Ridder, Dr. G.H. Koek, and Dr. C.M. Bakker for their help with the DJBL procedures; Prof. Dr. A.A. Masclee, Dr. J. Maljaars, and Y. Slaats for their help regarding the study design, and Dr. I.C. Arts and E. Theunisz for the Luminex analyses.

Clinical Trial Registration Number: NCT00985114

Conflict of Interest N.D.B. and J.W.M.G. disclose the following financial relationships relevant to this publication. N.D.B. received an open research grant from GI dynamics. J.W.M.G. received consultancy fees an open research grant and support for travel to meetings for the study or other purposes from GI dynamics. All other authors have no conflicts of interest relevant to this article.

Grant Information C.J., N.D.B. and J.W.M.G. disclose the following financial relationships relevant to this publication. C.J. received support for travel to meetings for the study or other purposes from GI dynamics. N.D.B. received an open research grant from GI dynamics. J.W.M.G. received consultancy fees an open research grant and support for travel to meetings for the study or other purposes from GI dynamics. All other authors have no conflicts of interest relevant to this work. 


\section{References}

1. Sjostrom L, Lindroos AK, Peltonen M, Torgerson J, Bouchard C, Carlsson B, et al. Lifestyle, diabetes, and cardiovascular risk factors 10 years after bariatric surgery. N Engl J Med. 2004;351(26):268393.

2. Kaplan LM. Pharmacological therapies for obesity. Gastroenterol Clin North Am. 2005;34(1):91-104.

3. Brolin RE. Bariatric surgery and long-term control of morbid obesity. JAMA. 2002;288(22):2793-6.

4. Borg CM, le Roux CW, Ghatei MA, Bloom SR, Patel AG, Aylwin SJ. Progressive rise in gut hormone levels after Roux-en-Y gastric bypass suggests gut adaptation and explains altered satiety. $\mathrm{Br} \mathbf{J}$ Surg. 2006;93(2):210-5.

5. le Roux CW, Welbourn R, Werling M, Osborne A, Kokkinos A, Laurenius A, et al. Gut hormones as mediators of appetite and weight loss after Roux-en-Y gastric bypass. Ann Surg. 2007;246(5):780-5.

6. Strader AD, Woods SC. Gastrointestinal hormones and food intake. Gastroenterology. 2005;128(1):175-91.

7. Wren AM, Bloom SR. Gut hormones and appetite control. Gastroenterology. 2007;132(6):2116-30.

8. Michalakis K, le Roux C. Gut hormones and leptin: impact on energy control and changes after bariatric surgery - what the future holds. Obes Surg. 2012;22(10):1648-57.

9. Considine RV, Sinha MK, Heiman ML, Kriauciunas A, Stephens TW, Nyce MR, et al. Serum immunoreactive-leptin concentrations in normal-weight and obese humans. N Engl J Med. 1996;334(5): $292-5$.

10. Zwirska-Korczala K, Konturek SJ, Sodowski M, Wylezol M, Kuka D, Sowa P, et al. Basal and postprandial plasma levels of PYY, ghrelin, cholecystokinin, gastrin and insulin in women with moderate and morbid obesity and metabolic syndrome. J Physiol Pharmacol : Off J Polish Physiol Soc. 2007;58 Suppl 1:13-35.

11. le Roux CW, Batterham RL, Aylwin SJ, Patterson M, Borg CM, Wynne KJ, et al. Attenuated peptide YY release in obese subjects is associated with reduced satiety. Endocrinology. 2006;147(1):3-8.

12. Tschop M, Weyer C, Tataranni PA, Devanarayan V, Ravussin E, Heiman ML. Circulating ghrelin levels are decreased in human obesity. Diabetes. 2001;50(4):707-9.

13. Cummings DE, Foster KE. Ghrelin-leptin tango in body-weight regulation. Gastroenterology. 2003;124(5):1532-5.

14. Meier U, Gressner AM. Endocrine regulation of energy metabolism: review of pathobiochemical and clinical chemical aspects of leptin, ghrelin, adiponectin, and resistin. Clin Chem. 2004;50(9): $1511-25$

15. le Roux CW, Aylwin SJ, Batterham RL, Borg CM, Coyle F, Prasad $\mathrm{V}$, et al. Gut hormone profiles following bariatric surgery favor an anorectic state, facilitate weight loss, and improve metabolic parameters. Ann Surg. 2006;243(1):108-14.

16. Beckman LM, Beckman TR, Earthman CP. Changes in gastrointestinal hormones and leptin after Roux-en-Y gastric bypass procedure: a review. J Am Diet Assoc. 2010;110(4):571-84.

17. Peterli R, Wolnerhanssen B, Peters T, Devaux N, Kern B, Christoffel-Courtin $\mathrm{C}$, et al. Improvement in glucose metabolism after bariatric surgery: comparison of laparoscopic Roux-en-Y gastric bypass and laparoscopic sleeve gastrectomy: a prospective randomized trial. Ann Surg. 2009;250(2):234-41.

18. Ochner CN, Gibson C, Shanik M, Goel V, Geliebter A. Changes in neurohormonal gut peptides following bariatric surgery. Int J Obes. 2011;35(2):153-66.

19. Peterli R, Steinert RE, Woelnerhanssen B, Peters T, ChristoffelCourtin C, Gass M, et al. Metabolic and hormonal changes after laparoscopic Roux-en-Y gastric bypass and sleeve gastrectomy: a randomized, prospective trial. Obes Surg. 2012;22(5):740-8.
20. Tymitz K, Engel A, McDonough S, Hendy MP, Kerlakian G. Changes in ghrelin levels following bariatric surgery: review of the literature. Obes Surg. 2011;21(1):125-30.

21. Korner J, Inabnet W, Febres G, Conwell IM, McMahon DJ, Salas $\mathrm{R}$, et al. Prospective study of gut hormone and metabolic changes after adjustable gastric banding and Roux-en-Y gastric bypass. Int $\mathrm{J}$ Obes. 2009;33(7):786-95.

22. Escalona A, Pimentel F, Sharp A, Becerra P, Slako M, Turiel D, et al. Weight loss and metabolic improvement in morbidly obese subjects implanted for 1 year with an endoscopic duodenal-jejunal bypass liner. Ann Surg. 2012;255(6):1080-5.

23. Schouten R, Rijs CS, Bouvy ND, Hameeteman W, Koek GH, Janssen IM, et al. A multicenter, randomized efficacy study of the endobarrier gastrointestinal liner for presurgical weight loss prior to bariatric surgery. Ann Surg. 2010;251(2):236-43.

24. de Jonge C, Rensen SS, Verdam FJ, Vincent RP, Bloom SR, Buurman WA, et al. Endoscopic duodenal-jejunal bypass liner rapidly improves type 2 diabetes. Obes Surg. 2013;23(9):1354-60.

25. Kreymann B, Williams G, Ghatei MA, Bloom SR. Glucagon-like peptide-1 7-36: a physiological incretin in man. Lancet. 1987;2(8571):1300-4.

26. van Dielen FM, Buurman WA, Hadfoune M, Nijhuis J, Greve JW. Macrophage inhibitory factor, plasminogen activator inhibitor-1, other acute phase proteins, and inflammatory mediators normalize as a result of weight loss in morbidly obese subjects treated with gastric restrictive surgery. J Clin Endocrinol Metab. 2004;89(8): 4062-8.

27. Miras AD, le Roux CW. Bariatric surgery and taste: novel mechanisms of weight loss. Curr Opin Gastroenterol. 2010;26(2):140-5.

28. Bueter M, le Roux CW. Gastrointestinal hormones, energy balance and bariatric surgery. Int J Obes. 2011;35 Suppl 3:S35-9.

29. Cummings DE, Overduin J. Gastrointestinal regulation of food intake. J Clin Invest. 2007;117(1):13-23.

30. Batterham RL, Cohen MA, Ellis SM, Le Roux CW, Withers DJ, Frost GS, et al. Inhibition of food intake in obese subjects by peptide YY3-36. N Engl J Med. 2003;349(10):941-8.

31. Huda MS, Wilding JP, Pinkney JH. Gut peptides and the regulation of appetite. Obes Rev. 2006;7(2):163-82.

32. Cummings DE, Shannon MH. Roles for ghrelin in the regulation of appetite and body weight. Arch Surg. 2003;138(4):389-96.

33. Sato T, Nakamura Y, Shiimura Y, Ohgusu H, Kangawa K, Kojima M. Structure, regulation and function of ghrelin. J Biochem. 2012;151(2):119-28.

34. Oswal A, Yeo G. Leptin and the control of body weight: a review of its diverse central targets, signaling mechanisms, and role in the pathogenesis of obesity. Obesity. 2010;18(2):221-9.

35. Maljaars PW, Symersky T, Kee BC, Haddeman E, Peters HP, Masclee AA. Effect of ileal fat perfusion on satiety and hormone release in healthy volunteers. Int J Obes. 2008;32(11):1633-9.

36. Maljaars PW, Peters HP, Mela DJ, Masclee AA. Ileal brake: a sensible food target for appetite control. A review. Physiol Behav. 2008;95(3):271-81.

37. Dockray GJ. Cholecystokinin. Curr Opin Endocrinol Diabetes Obes. 2012;19(1):8-12.

38. Verhulst PJ, Depoortere I. Ghrelin's second life: from appetite stimulator to glucose regulator. World J Gastroenterol. 2012;18(25): 3183-95.

39. Ariyasu H, Takaya K, Tagami T, Ogawa Y, Hosoda K, Akamizu T, et al. Stomach is a major source of circulating ghrelin, and feeding state determines plasma ghrelin-like immunoreactivity levels in humans. J Clin Endocrinol Metab. 2001;86(10):4753-8.

40. Woods SC, D'Alessio DA. Central control of body weight and appetite. J Clin Endocrinol Metab. 2008;93(11 Suppl 1):S37-50.

41. Bradley D, Conte C, Mittendorfer B, Eagon JC, Varela JE, Fabbrini $\mathrm{E}$, et al. Gastric bypass and banding equally improve insulin sensitivity and beta cell function. J Clin Invest. 2012;122(12):4667-74. 
42. de Moura EG, Orso IR, Martins Bda C, Lopes GS, de Oliveira SL, Galvao-Neto Mdos P, et al. Improvement of insulin resistance and reduction of cardiovascular risk among obese patients with type 2 diabetes with the duodenojejunal bypass liner. Obes Surg. 2011;21(7):941-7.
43. Evans S, Pamuklar Z, Rosko J, Mahaney P, Jiang N, Park C, et al. Gastric bypass surgery restores meal stimulation of the anorexigenic gut hormones glucagon-like peptide-1 and peptide YY independently of caloric restriction. Surg Endosc. 2012;26(4):1086-94. 